\title{
RAINFALL - OCEAN FAUNAL INTERACTIONS, CARTERET COUNTY, NORTH CAROLINA
}

\author{
HUGH J. PORTER, GLENN SAFRIT, and FRANK J. SCHWARTZ
}

Institute of Marine Sciences, University of North Carolina, Morehead City, NC 28557-3209

\begin{abstract}
Rainfall data collected at the Institute of Marine Sciences (IMS) for the years 1983-2011 varied between $0.51(12.9 \mathrm{~mm})$ and $0.75(19.1 \mathrm{~mm})$ inches/day/yr. Storms, hurricanes and natural events greatly influenced the data. Hurricanes, run off, flooding and El Nino, and La Nina events influenced increases and decreases in precipitation pre-1990 and post-1990. Shark, finfish and shrimp catches varied in response to storm effects on the nearby river and ocean water temperatures. Significant statistical differences existed between rainfall and shark catches.
\end{abstract}

Key Words: rainfall; storms; hurricanes; sharks; finfish; shrimp.

\section{INTRODUCTION}

Environmental data has been recorded at the Institute of Marine Sciences (IMS), Morehead City, Carteret County, North Carolina since 1947, rainfall since 1967 (Porter 1985). Porter (1985) analyzed IMS 1979-1981 rainfall noting yearly means of 0.147 inches: $3.73 \mathrm{~mm} /$ day/yr. Questions arose: have rainfalls been static during subsequent years 1983-2011; has rainfall at IMS and the adjacent Atlantic Ocean been influenced by storms and hurricanes: and did rainfall and hurricane runoff, flooding and other influences affect shark, finfish and shrimp catches? Answers would shed light on these rainfall/faunal interrelationships.

\section{METHODS}

Rainfall, was collected, during the years 1983-2011, using a rain and snow gauge, U.S. Weather Bureau spec. no. 450-231, Science Associates inc. Model 503 gauge set unobstructed a few meters away from IMS and nearby vegetation. Rainfall was measured as inches/day ( 1 in. = $25.4 \mathrm{~mm}$ ). Yearly, rainfall data was collated and depicted graphically as: means, standard deviations, standard errors of the means and ranges (Fig. 1) using R, ver. 2.15.0 R Development Core Team2012 computer program.

An analysis of variance (ANOVA) tested yearly 19732011 rainfall and shark catch trends. Linear regressions, $\mathrm{y}=\mathrm{a}+\mathrm{b} \times$ were fitted to Onslow Bay 1972-2011 shark longline catch trends (Fig. 2).

\section{OBSERVATIONS}

\section{Rainfall}

Yearly rainfall increased significantly after 1988 ( $\mathrm{f}=$ $778,38 \mathrm{df*}$ ) from averages of $705 \mathrm{~mm}$ (47.03 in/yr) in pre 1998 to $1,209 \mathrm{~mm}$ (51.6 in/yr) during 1999-2011. Yearly
IMS rainfall varied $0.51 \mathrm{in} /$ day $(12.95 \mathrm{~mm} /$ day $)$ during 1983-1999 and 0.75 in: (19.1/day mm) during 2000-2011

(Table 1).

Heaviest rainfalls occurred during August 1999 (Hurricane Dennis, 19 inches, $506 \mathrm{~mm}$ ), September 1999 (Hurricane Floyd 20 inches $(500 \mathrm{~mm})$ and September 2005 (Hurricane Ophelia 17.5 inches (445 mm) Table 1. Yearly, rainfall increased after 1990, ANOVA f $=7.38$, $38 \mathrm{df}^{*}$.

\section{Hurricanes}

IMS and adjacent ocean areas were subject to 18 hurricanes between 1983-2011 (Fig. 1). Most occurred in August (7) and September (8) (Table 1). Hurricanes Floyd and Fran caused the most runoff and flooding in eastern North Carolina and influenced water temperatures. Hurricane Fran (September 1996) was the fiercest, arriving at $130 \mathrm{mph}(220 \mathrm{~km} / \mathrm{hr})$ and caused $10 \mathrm{ft}$. (3 m) storm surges. Hurricane Floyd (1999) velocity was $197 \mathrm{~km} / \mathrm{hr}$ and caused $10 \mathrm{ft}(3 \mathrm{~m})$ storm surges.

Hurricanes Dennis (September 1984) caused 3 deaths, Fran (September 1996) 14, Floyd (September 1999) 35, and Irene (September 2011) 13 (Table 1).

\section{Sharks}

Yearly shark longline catches between 1973-2011 in Onslow Bay, expressed as catch/unit/effort (CPUE), varied between 0.167 sharks/hook in 1973 and 0.18 in 2003 (Fig. 2). Linear regressions of these variations were : $\mathrm{y}=-0.165 \times-1.024, \mathrm{r}^{2}=0.47$ (yrs 1973-1990) $\mathrm{f}=0.0478$ and $\mathrm{y}=0.5152 \times-2.013, \mathrm{r}^{2}=0.0804$, (years 2000-2011). Long-line catches were greater during pre-1990 and lower post 1990 (when ocean water temperatures shifted significantly $\mathrm{f}=6.40$, df 38 (from cooler pre 1990 to warmer 1990 yrs (Schwartz et al. 2010). 


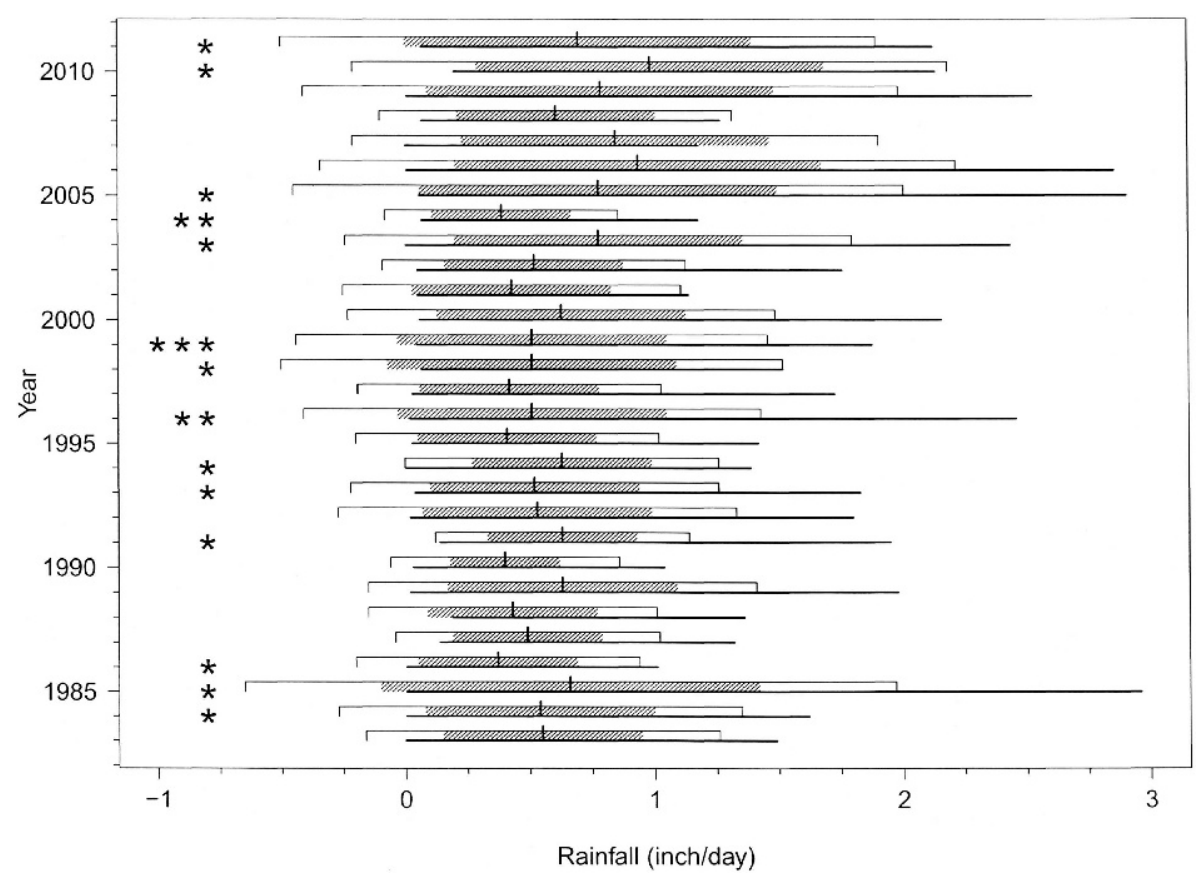

FIG. 1. Rainfall, depicted by year as inches/yr: mean, standard deviations, open bars; standard errors of the mean, stippled bars; range, solid lines at the bottom of each year. 1 in $=25.4 \mathrm{~mm}$.

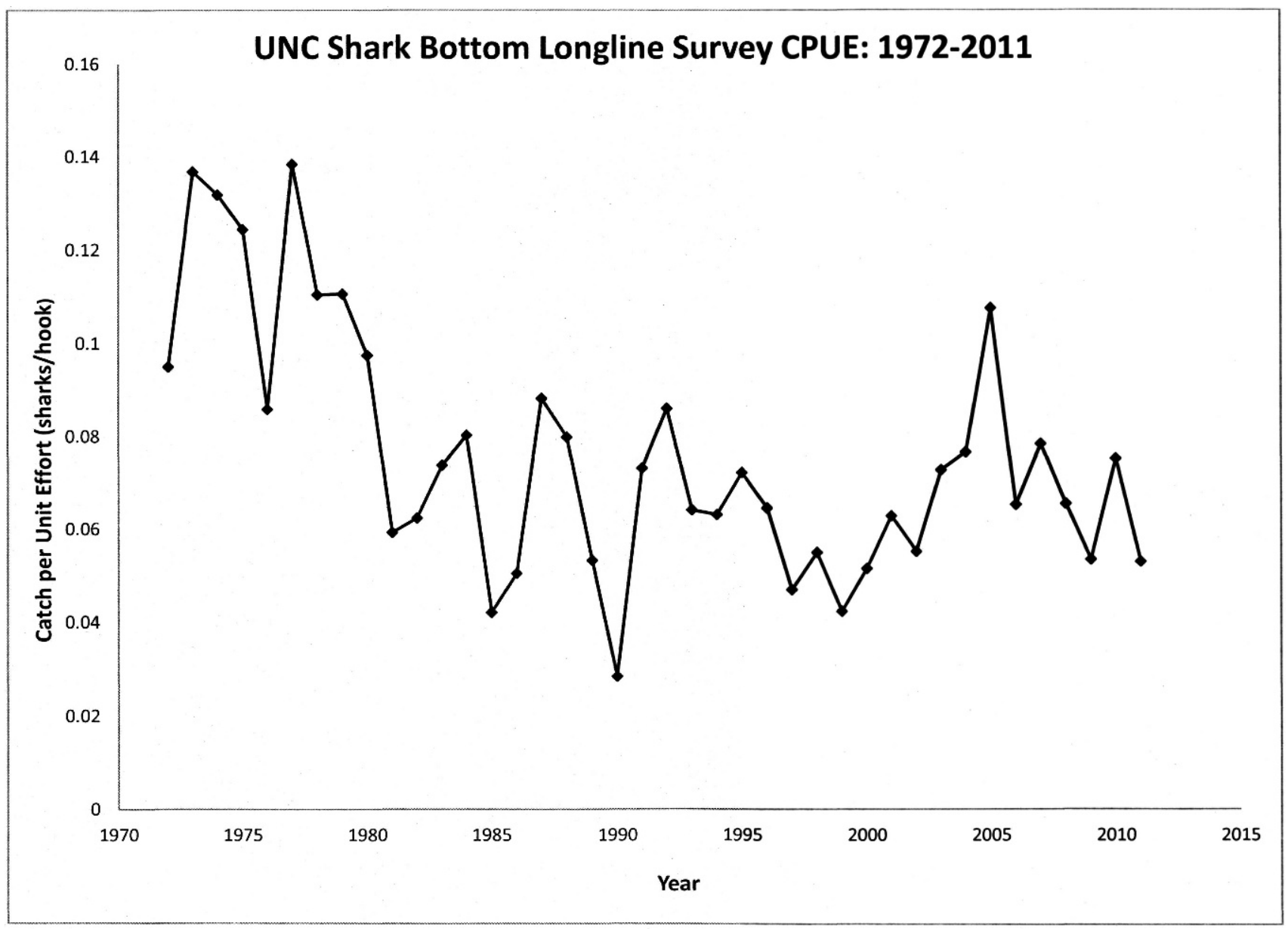

FIG. 2. Yearly shark longline catch per unit effort (CPUE) during 1972-2011. 
Table 1. Year and dates of 18 hurricanes occurring during 19832011 and the Atlantic Ocean caused flooding and deaths.

\begin{tabular}{lllc}
\hline Year & \multicolumn{1}{c}{ Date } & Hurricane & Death (n) \\
\hline 1984 & 13 September & Adriane & 3 \\
1985 & 27 September & Gloria & 1 \\
1986 & 17 August & Charley & 1 \\
1991 & 19 August & Bob & 1 \\
1993 & 23 September & Emily & 2 \\
1994 & 27 November & Gordon & - \\
1996 & 12 July & Bertha & 1 \\
1996 & 6 September & Fran & 6 \\
1998 & 21 August & Bonnie & 1 \\
1999 & 30 August & Dennis & - \\
1999 & 16 September & Floyd & 35 \\
1999 & 18 October & Irene & 1 \\
2003 & 18 September & Isabelle & 3 \\
2004 & 2 August & Alex & 1 \\
2004 & 14 August & Charley & 3 \\
2005 & 14 October & Ophelia & - \\
2010 & 19 September & Igor & 1 \\
2011 & 27 August & Irene & 7 \\
\hline
\end{tabular}

\section{Finfish}

Commercial finfish landings varied greatly, similar to shark catches (Table 2): greater during pre 1983 1990 yrs, smaller during post warmer years 1991-2011.

\section{Shrimp}

Shrimp catches varied, similar to finfish catches, greater during cooler water years (1973-1999 and smaller during warmer water years (2000-2011) (Table 2).

\section{DISCUSSION}

Most people are oblivious that North Carolina's IMS rainfall and ocean faunas were intricately interrelated as a result of precipitation, storms, and distant El Nino and La Nina influences. Local precipitations cause runoff and flooding that affected river nutrient loads in the adjacent ocean (Drinkwater 1986; Christian et al. 1991; Bales 2003; Boyles et al. 2004; Paerl et al. 2006; Cahoon 2013).

Hurricane precipitation drastically affected Atlantic ocean water temperatures between 1972-1994 vs. 1995-2011; as cooler waters occurred between 1972 1999 vs. warmer waters during 2000-2011 (Goldenberg 2001; Schwartz et al. 2010). Schwartz et al. (2010) noted water temperature shifts and the effects on shark longline catches in Onslow Bay. As ocean water temperatures, increased ice cap melting is occurring and in turn increasing hurricane activity in various parts of the world (Delworth et al. 2007). El Nino events (where Pacific ocean waters are warmer) decreased winter and increased summer precipitation. La Nina reversed these events and increased summer and fall hurricanes (Boyles et al. 2004). Decreased
Table 2. Finfish and shrimp catch landings (lbs) for years 19832011. Hurricane years denoted by * symbol. Commercial finfish and shrimp landings (in lbs) off Carteret county, North Carolina 18932011. $1 \mathrm{lb}=0.454 \mathrm{~kg}$.

\begin{tabular}{|c|c|c|c|}
\hline Year & Fish & Shrimp & Hurricane $(*)$ \\
\hline 1983 & $129,082,192$ & 468,060 & \\
\hline 1984 & $157,372,451$ & 408,549 & * \\
\hline 1985 & $103,000,310$ & 612,184 & * \\
\hline 1986 & $16,489,509$ & 458,782 & $*$ \\
\hline 1987 & $64,340,750$ & 552,421 & \\
\hline 1988 & $82,644,057$ & 680,820 & \\
\hline 1989 & $69,105,946$ & 617,56 & \\
\hline 1990 & $71,340,370$ & 266,259 & \\
\hline 1991 & $109,336,418$ & 241,674 & $*$ \\
\hline 1992 & $6,1979,839$ & 182,070 & \\
\hline 1993 & $75,154,144$ & 500,134 & $*$ \\
\hline 1994 & $79,980,308$ & 351,330 & $*$ \\
\hline 1995 & $68,035,721$ & 447,861 & \\
\hline 1996 & $68,406,569$ & 395,738 & $* *$ \\
\hline 1997 & $85,259,462$ & 261,998 & \\
\hline 1998 & $67,959,697$ & 598,648 & $*$ \\
\hline 1999 & $46,028,001$ & 519,672 & $* * *$ \\
\hline 2000 & $59,470,409$ & 270160 & \\
\hline 2001 & $57,581,859$ & 118,369 & \\
\hline 2002 & $73,094,559$ & 157,435 & \\
\hline 2003 & $50,737,774$ & 549947 & $*$ \\
\hline 2004 & $53,801,249$ & 257,952 & $* *$ \\
\hline 2005 & $14,725,137$ & 107,596 & $*$ \\
\hline 2006 & $2,468,225$ & 188,664 & \\
\hline 2007 & $2,068,381$ & 343,011 & \\
\hline 2008 & $1,907,796$ & 180,354 & \\
\hline 2009 & $2,139,498$ & 94,610 & \\
\hline 2010 & $2,510,089$ & 119,269 & $*$ \\
\hline 2011 & $2,080,902$ & 75,834 & $*$ \\
\hline
\end{tabular}

local precipitation affected North Carolina invertebrate faunas (Kirby- Smith and Ustach 1986); Bell and Hall (1999), while sharks (Dogfish and blacknose sharks) simply swam away from hurricane front influences (Gibson 1980; Fiedler and Bernard 1987; Fraser and Shelmerdine 2002; Heupel et al. 2003) and once their skin hair cells sensed hurricane hydrostatic pressure changes. Black tipped sharks vacated an area during heavy rainfalls (Heupel et al. 2003). Pelagic tuna and bottom fishes also responded similarly by swimming away from an affected area (Power and May 1994; Russel 1997; Watterson et al. 1998; Kirby et al. 2000).

\section{CONCLUSIONS}

Thus, rainfalls are a result of many intricately interrelated events. Rainfall varied at IMS every year. Variations influenced runoff, flooding, while ocean temperature changes influenced shark, finfish, and shrimp populations. Knowledge of these interrelationships would help us better utilize our ocean faunas, on which we depend, and understand the input of rainfall, storms and hurricanes on an area. 
Acknowledgments: $\quad$ Ben Peierls created Figure 1. S. Mclnemy North Carolina Division of Marine Fisheries provided ocean finfish and shrimp landing information. C. McCandless National Marine Fisheries Service Narragansett, RI furnished the Onslow Bay CPUE shark data. Librarians P. Mararo NOAA and J. Miller Duke Marine Lab, Beaufort, NC furnished several important references. To all we owe our thanks.

\section{LITERATURE CITED}

BALES, J. D. 2003. Effects of Hurricane Floyd on inland flooding September-October 1999, and tributaries to Pamlico Sound, North Carolina. Estuaries 26:1319-1328.

BELL, M., AND J. W. HALL. 1994. Effects of Hurricane Hugo on South Carolina's Marine artifical reefs. Bull. Mar. Sci. 55(2-3):836-847.

BOYleS, R. P., C. HOLDER, AND S. RAMAN. 2004. North Carolina Climate: A survey of Climate normals and averages at 18 Agricultural Research Stations; North Carolina Agricultural Res.Serv. Tech. Bull. 322, 92 p.

CAHOON, L. B. 2012. Southern Oscillation Effects on river fishes of the lower Cape Fear River watershed, North Carolina. J. No. Car. Acad. Sci. 128(3-4):74-80.

CHRISTIAN, R. R., J. N. BOYER, AND D. W. STANLEY. 1991. Multi- year distribution patterns of nutrients within the Neuse River estuary. Mar. Ecol. Prog. Ser. 71:259-274.

DELWORTH, T. H., H. R. ZHANG, AND E. MANN. 2007. Decadal to Centennial variability. Pp. 131-148 in A. Schmitner, P. C. H. Shang, and S. R. Hemming (eds.), Ocean Circulation: Mechanisims and Impacts - Past and future changes on Meridional overturning. Geophysical Union Monogr. Ser. 173

DRINKWATER, K. F. 1989. Climate, freshwater run-off and fisheries. Bedford Inst. Oceanogr. Biol. Rev. 84:33-34.

FIEDLER, P., AND H. BERNARD. 1987. Tuna aggregations and feeding at ocean fronts observed in satellite imagery. Coast. Shelf Res. 7:871-881.

FRASER, P. J., AND R. I. SHELMERDINE. 2002. Dogfish hair cells sense hydrostatic pressure. Nature 4015(37):495-496.
GIBSON, R. N. 1984. Hydrostatic pressure and rhythmic behaviour of intertidal marine fishes. Trans. Amer. Fish. Soc. 113(4): 479-483.

GOLDENBERG, S. P., C. W. LANDSEA, A. M. MESTASNUNEZ, AND W. M. GREY. 2001. The recent increase activity: hurricane activity : causes and implications. Science 293(5529):438-474.

HEUPEL, M. R., C. A. SIMPFENDORFER, AND R. E. HEUTER. 2003. Running before the storm, Blacktip sharks response to falling barometric pressure associated with tropical storm Gabriella. J. Fish. Biol. 63:1357-1363.

KIRBY, D. S., OFIKSEN, AND J. B. HART. 2000. A dynamic optimisation model for behaviour of tunas at ocean fronts. Fish. Oceanogr. 9(4):328-342.

KIRBY- SMITH, W., AND J. USTACH. 1986. Resistance to Hurricane disturbance of an epifaunal community off the continental shelf of North Carolina. Estuarine Coast Shelf Sci. 23:433-442.

PAERL, H. W., L. M. VALDES, M. F. PIEHLER, AND C. A. STONE. 2006. Assessing the effects of nutrient management in an estuary experiencing climate change. The Neuse River estuary, North Carolina. Environ. Mgt. 37(30):422-436.

PORTER, H. J. 1985. Three year environmental Atlas. (1979-1981). University of North Carolina Institute of Marine Sciences and adjoining Bogue Sound. UNC Chapel Hill, Institute of Marine Sciences, Morehead City, NC. 86 p.

POWER, J. H., AND L. N. MAY. 1991. Satellite observed sea-surface temperatures and yellowfin tuna catch and effort in the Gulf of Mexico. Fish. Bull. 89:429-439.

RUSSEL, M. 1977. Apparent Effect of flooding on distribution of intertidal bottom fish in the Northern Gulf of Mexico. NE Gulf Sci. 1(2):77-78.

SCHWARTZ, F. J., J. PURIFOY, G. SAFRIT, AND R. CHURCHILL. 2010. Variations in Shark longline catches during 19722008: Real or inferred? J. No. Car. Acad. Sci. 126(1):128130.

WATTERSON, J. C., W. F. PATTERSON III., R. L. SHIPP, AND J. H. COWAN JR. 1998. Movement of Red snapper Lutjanus campechanus in the north central Gulf of Mexico. Potential effects of Hurricanes. Gulf Mexico Sci. 16(1):92-104. 